\title{
Evaluation of upper Uruguay river basin (Brazil) operational flood forecasts
}

\section{Avaliação de previsões de cheias operacionais para a bacia do alto rio Uruguai (Brasil)}

\author{
Fernando Mainardi Fan ${ }^{1}$, Paulo Rógenes Monteiro Pontes ${ }^{2}$, Diogo Costa Buarque ${ }^{3}$ and Walter Collischonn ${ }^{1}$ \\ ${ }^{1}$ Universidade Federal do Rio Grande do Sul, Porto Alegre, RS, Brazil \\ ${ }^{2}$ Universidade do Vale do Rio dos Sinos, São Leopoldo, RS, Brazil \\ ${ }^{3}$ Universidade Federal do Espírito Santo, Vitória, ES, Brazil \\ E-mails: fernando.fan@ufrgs.br (FMF),p.rogenes@gmail.com (PRMP), diogo.buarque@gmail.com (DCB), collischonnn@iph.ufrgs.br (WC)
}

\begin{abstract}
System for hydrological forecasting and alert running in an operational way are important tools for floods impacts reduction. The present study describes the development and results evaluation of an operational discharge forecasting system of the upper Uruguay River basin, sited in Southern Brazil. Developed system was operated every day to provide experimental forecasts with special interest for Barra Grande and Campos Novos hydroelectric power plants reservoirs inflow, with 10 days in advance. We present results of inflow forecasted for floods occurred between July 2013 to July 2016, the period which the system was operated. Forecasts results by visual and performance metrics analysis showed a good fit with observations in most cases, with possibility of floods occurrence being well predicted with antecedence of 2 to 3 days. Comparing the locations, it was noted that the sub-basin of Campos Novos, being slower in rainfall-runoff transformation, is easier forecasted. The difference in predictability between the two basins can be observed by the coefficient of persistence, which is positive from $12 \mathrm{~h}$ in Barra Grande and from $24 \mathrm{~h}$ to Campos Novos. These coefficient values also show the value of the rainfall-runoff modeling for forecast horizons of more than one day in the basins.
\end{abstract}

Keywords: Flood forecasting; Hydrological modeling; Uruguay River.

\section{RESUMO}

Sistemas operacionais de previsão hidrológica e alerta são ferramentas úteis para a redução de impactos das inundações. Este estudo apresenta o desenvolvimento e uma avaliação dos resultados de um sistema de previsão de vazão operacional para a bacia do alto rio Uruguai, localizada no sul do Brasil. O sistema foi operado diariamente para fornecer previsões experimentais com interesse especial nas afluências dos reservatórios das usinas hidrelétricas de Barra Grande e Campos Novos, com antecedência de 10 dias. Aqui são apresentados resultados das previsões de afluências para as principais cheias ocorridas entre julho de 2013 e julho de 2016 , período no qual o sistema foi operado. Os resultados das previsões por análise visuais e de métricas de desempenho mostraram um bom ajuste com observações na maioria dos casos, prevendo a possível ocorrência de inundações com 2 a 3 dias de antecedência. Na comparação entre as duas bacias notou-se que um a sub-bacia de Campos Novos, por ser mais lenta na transformação chuva-vazão, é mais fácil de ter suas vazões previstas. A diferença na previsibilidade entre as duas bacias pode ser observada pelo coeficiente de persistência, que é positivo a partir de $12 \mathrm{~h}$ em Barra Grande e a partir de $24 \mathrm{~h}$ para Campos Novos. Estes valores de coeficiente também mostram a importância da transformação chuva-vazão para a previsão de horizontes de mais de um dia nas bacias.

Palavras-chave: Previsão de cheias; Modelagem hidrológica; Rio Uruguai. 


\section{INTRODUCTION}

Floods events are one of the several natural disasters occurring on the world that cause severe impacts to populations in socioeconomic terms (MOORE; BELL; JONES, 2005). The occurrences of floods observed recently in Brazil has been followed by an increasing interest from sectors of society in measures that allow to anticipate these events, reducing their impact in terms of lives and property damage (FAN; PAIVA; COLLISCHONN, 2016). In this sense, alert systems are one of the most effective measures (ALFIERI et al., 2012).

Early warning systems have main purpose of predict the future possibility of a river floods occurrence and its related characteristics at vulnerable sites with time advance and acceptable accuracy, to issue warnings to those responsible for civil defense, the water consumers, the local population and the hydraulic structures operators in the region (FAN et al., 2016; ALFIERI et al., 2012; MOORE; BELL; JONES, 2005; TACHINI, 2003). The main component of any early warning system is a system for flood forecasts.

Flood forecasting systems are especially important for basins having fast runoff, a characteristic behavior of several brazilian river basins, mainly those located in the South region. One of them is the upper Uruguay river basin (see Figure 1), located in the Serra Geral geological formation, a region dominated by basalts soils and rocks (NARDY et al., 2002). The basin geological framework provides a very fast response to rainfall events that, consequently, may produce unexpected floods. Summed to this, the absence of precipitation seasonality allows the occurrence of sudden river discharge increases at any time of the year.

In addition, researches related to forecasting systems evaluation are important to show potential benefits of tested techniques and products and to allow a better understanding of the modelled systems. Based on the forecasts, developments can be planned to improve accuracy (ALFIERI et al., 2014). Also, in the context of operational use, investigations help to highlight the current system problems, whose must be considered when forecast results are to be used for decision making (PAGANO et al., 2014).
Some examples of streamflow forecasting studies focusing on its results verifications can be found in recent literature: Bergh and Roulin (2010), Thiemig et al. (2010), Schellekens et al. (2011), Bao et al. (2011), Addor et al. (2011), Boucher et al. (2011), Bourdin and Stull (2013), Alfieri et al. (2014), Pagano (2014), Fan et al. (2014, 2015a,c), Siqueira et al. (2016a) and Casagrande et al. (2017).

From these cited references, the work of Bergh and Roulin (2010) presented the forecasting systems from the Belgium Royal Meteorological Institute (RMI) for rivers Meuse and Scheldt (in Europe, with areas ranging from 590 to $2440 \mathrm{~km}^{2}$ ) with 9 days of forecast horizon. Results of the model were evaluated for a hindcasting experiment between February 2006 and March 2009. The authors concluded that the forecasts perform well until the most distant forecast horizon and that it has economic value added through a specific evaluation metric.

Thiemig et al. (2010) evaluated the feasibility of forecasts with up to 10 days horizon in two locations in East Africa, one site in the Juba River Basin $\left(166,000 \mathrm{~km}^{2}\right)$ and one in the Shabelle River Basin $\left(207,000 \mathrm{~km}^{2}\right)$. Basically, the experiment consisted of reproducing the EFAS system technology (THIELEN et al., 2009) for the African basins. Results showed that the forecasting system could predict about $85 \%$ of the flood cases evaluated with good accuracy.

The work of Addor et al. (2011) shows an assessment of a forecasting system for the Sihl river basin $\left(336 \mathrm{~km}^{2}\right)$, which flows through Zurich (Switzerland) and has been operational since 2008. Data from the COSMO-7 and the COSMOLEPS meteorological models are considered as a forcing in the hydrological model. The results of several metrics used by the authors indicated benefits in the use of predictions from COSMOLEPS. The authors also found that the two major rainfall events in the basin during the evaluation period were generally underestimated.

In the paper of Schellekens et al. (2011), the authors evaluated the performance of the regional forecasting system called MOGREPS (Met Office Global and Regional Ensemble Prediction System) for flood prediction in the Thames River basin in the United Kingdom. The MOGREPS version used has a resolution of $24 \mathrm{~km}$ and a forecast horizon of three days.

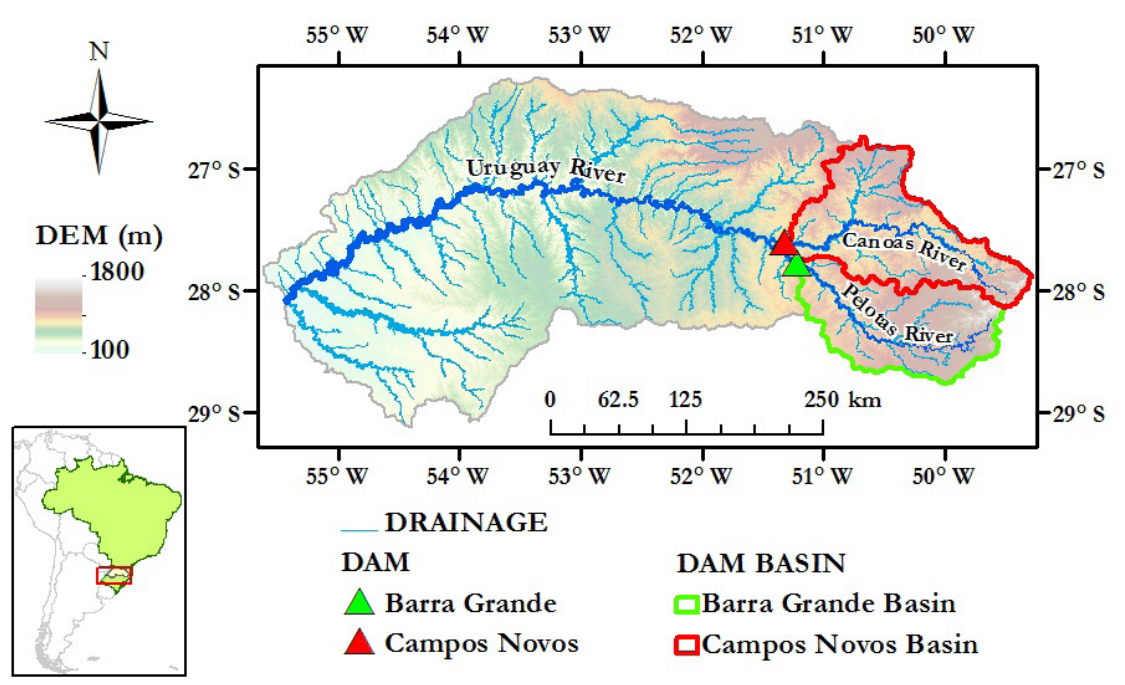

Figure 1. Location of the upper Uruguay river in Brazil. Highlight is given to the main basins of interest. 
The hydrological model used was the TCM (Thames Catchment Model), with a procedure of output corrections. As conclusions, the authors cite that MOGREPS predictions resulted in good flood forecasts across the Thames region. The frequency of false alarms in the evaluated period was low, and the smaller events (below alert limits) were also well predicted.

In the study by Bourdin and Stull (2013) the authors present a verification of forecasts of inflows to a hydroelectric plant reservoir in the Cheakamus river basin $\left(721 \mathrm{~km}^{2}\right)$ in Canada. The forecasting system used multiple meteorological models connected to multiple hydrological models through different downscaling schemes. The major goal of such a complex forecasting system was to sample all possible uncertainties in the process, and include them in the results. The authors concluded that the inclusion of all uncertainties increased the resolution and the capacity of event discrimination of the system, and that the removal of bias allowed to use the maximum potential of the system.

Alfieri et al. (2014) presented a complete evaluation of the flow forecasts from the EFAS (European Flood Awareness System) to various locations in Europe. According to the authors, the performance metrics showed that the forecasts have dexterity for medium and small basins for up to ten days in advance. For smaller and mountainous basins, the results are still not very suitable.

Pagano (2014) presents an evaluation of the historical record of flood forecasts runned in an operational way by the Regional Flood Management and Mitigation Center (RFMMC) of the Mekong River Commission (Southeast Asia). The RFMMC issues daily deterministic forecasts of river height with 1 to 5 days in advance throughout the wet season (June-October) for 22 locations of interest. Results evaluated by skill scores shows a good performance of the forecasts, mainly in regions presenting a strong seasonal cycle and a narrow natural range of variability. On the other hand, a moderate probability of detection of $48 \%$ and $31 \%$ at 1 and 5 days ahead, respectively, and false alarm rate of $13 \%$ and $74 \%$ at 1 and 5 days ahead, respectively were observed in the forecasts results evaluated from a categorical "crossing above/not-crossing above flood level" perspective.

More recently, the study from Siqueira et al. (2016a) aimed to assess both the quality of ensemble flood forecasts on Taquari-Antas (RS, Brazil) basin and its potential to provide additional information to a local Flood Alert System. On a single event evaluation, the peak discharge was reasonable well predicted by at least one ensemble member, in nearly all forecasts, with a good prediction of the flood timing for the considered lead times. An overall tendency of underestimation was also identified, since most of the observed values was between the higher ranks of the ensemble. Results suggest that there is a benefit in having hydrological ensemble forecasts, which can be used as a complementary information to a local Flood Alert System supporting pre-alert issues and Civil Defense internal planning actions.

In general, all these studies provide useful insights of the forecasting systems performances. They present assessment studies of pre-operational or operational forecasting systems and contribute to the current knowledge about methodologies and hydro-meteorological forecasting performances at multiple locations.

Considering the exposed above, the present study describes the development and results evaluation of an experimental operational discharge forecasting system of the upper Uruguay River basin, which is based on a large-scale distributed hydrological model. The hydrological model is used to estimates river discharges forced by observed and predicted rainfall as inputs. The system may provide experimental deterministic forecasts at several locations of the basin. The present study case could be operationally useful because the information generated could be considered, for example, for better operations of two hydropower plants (HPP) reservoirs: Campos Novos HPP; and Barra Grande HPP (Figure 1). Although the basins are located close to each other, the complexity of inflow forecasting generation to the dams differs due to regional hydrological features, which interacts with meteorological uncertainties.

The system was operated in operational mode once a day from July 2013 to July 2016. The following sessions contain a description of the main features of the developed system and the results of forecasts of reservoirs inflows for the largest floods occurred during the operational period.

As the referenced commented studies, this work also aimed to contribute to the current knowledge about forecasting performances, especially related to understanding the operational feasibility of the techniques applied and the data used for basins such as those studied. In addition, it is done a comparative analysis of how sub-basins close in space may present different performances. The hypothesis of the study is that the developed system is suitable for forecasts in the region, which is evaluated by an analysis of the forecasts performed. In the presented case, accurate forecasts can be translated into improved decisions relating to energy generation, dam safety and flood control through hydraulic structures operation.

\section{FORECASTING SYSTEM OVERVIEW}

Rainfall and discharge data from telemetric gauges spatially distributed within the basin are used by the forecast system of the upper Uruguay river basin. The system also uses Quantitative Precipitation Forecasts (QPF) from meteorological models as input data to provide streamflow forecasts ten days in advance at multiple locations in the basin. If necessary upstream boundary conditions can also be used, as the programmed outflow of Dams. Figure 2 presents an illustrative workflow of the forecasting system. All data is processed in the MGB-IPH hydrological model (COLLISCHONN et al., 2007; FAN; COLLISCHONN, 2014; PONTES et al., 2015, 2017) described in the following section.

Using the system requires rainfall data recorded by a telemetric gauges network for a recent past. All rainfall information is interpolated by the inverse distance weighted method to assess the spatial patterns of rainfall across the basin before be used in the hydrological model as input information. Also, at defined locations within the basin, the streamflow time series for the recent past are derived using the estimative of water levels from telemetric gauges and its respective rating curves to generate streamflow time series for the recent past. These series area used through a data assimilation scheme implemented in the MGB-IPH (described later in this paper). Table 1 presents the name and location (geographic coordinates) of all telemetric gauges used in the presented system, they are used to measure both rainfall and water levels. 


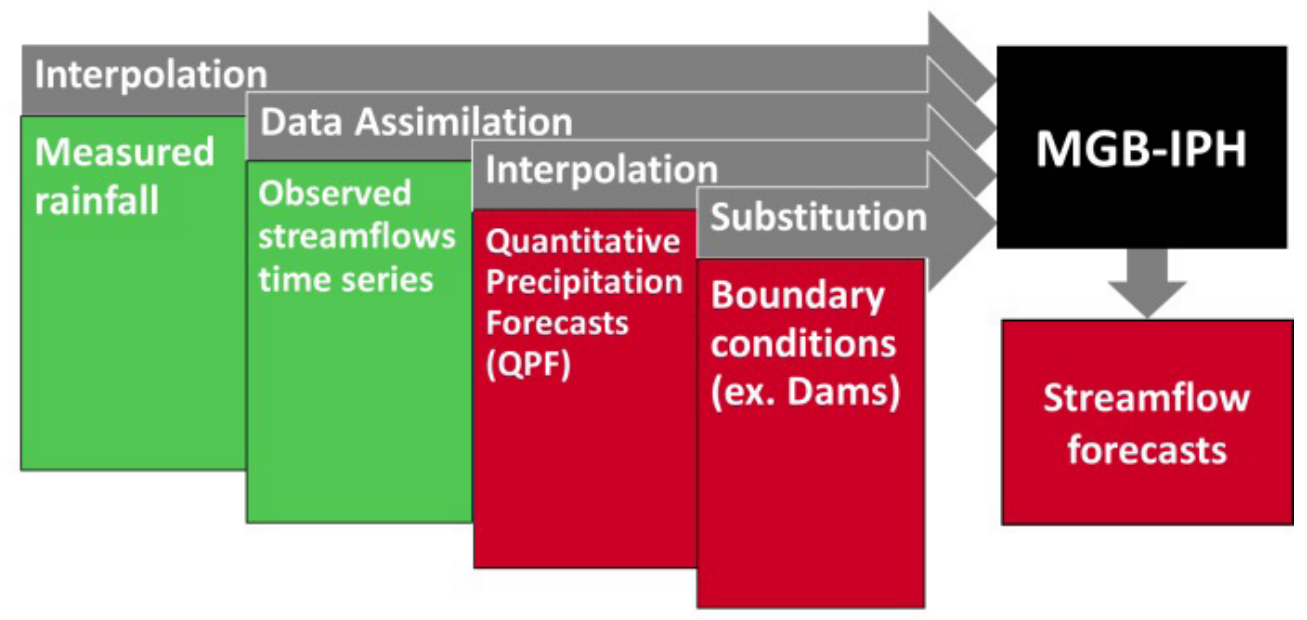

Figure 2. Illustrative workflow of the forecasting system. Green boxes indicate observed (past) data and red boxes indicate modeled/ inferred (future) data.

Table 1. List of telemetric gauges (rainfall and water level) used in the system.

\begin{tabular}{cclc}
\hline ID & Nome & Lat & Long \\
\hline 1 & Passo-do-Honorato & -28.3944 & -50.5756 \\
2 & Santana & -28.2628 & -50.7608 \\
3 & Socorro & -28.2869 & -50.8333 \\
4 & Vacas-Gordas & -28.02 & -50.7822 \\
5 & Barra Grande & -27.7758 & -51.1908 \\
6 & Bocaina do Sul & -27.6557 & -49.9524 \\
7 & Ponte Alta & -27.486 & -50.3916 \\
8 & Travessão & -27.6713 & -50.7097 \\
9 & Garibaldi & -27.6232 & -50.9856 \\
10 & Campos Novos & -27.6065 & -51.3282 \\
\hline
\end{tabular}

The streamflow forecasting process also needs data about the future rainfall, over the forecasted lead times. For research purposes, in the present study, it was used Quantitative Precipitation Forecasts (QPF) from the Numerical Weather Prediction (NWP) model Eta-15km. The Eta-15km, which has $15 \mathrm{~km}$ of grid resolution, provides future rainfall predictions over all South America. The Eta model data have a forecast horizon of 7 days and are available twice a day by the webpage of the Brazilian meteorological center CPTEC ("Centro de Previsão de Tempo e Estudos Climáticos", in Portuguese).

The system results were daily monitored by a research team that included the system developers. The total lead time of the distributed hydrological forecasts by the system was ten days (240 hours). The first 7 days of the forecasting horizon used the CPTEC Eta-15km rainfall forecasts as inputs, and the last 3 days considered a null precipitation over the watershed area.

\section{MGB-IPH HYDROLOGICAL MODEL DESCRIPTION}

The MGB-IPH (Modelo de Grandes Bacias - Instituto de Pesquisas Hidránlicas) is a large-scale hydrological model that calculates the hydrological processes into a catchment through climate variables, physiographic data and soil and land type data (COLLISCHONN et al., 2007; FAN; COLLISCHONN, 2014; PONTES et al., 2015, 2017).

The MGB-IPH is a distributed hydrological model and the basin is subdivided into minor units (catchments) using Geographical Information Systems (GIS) tools in a stage of data pre-processing (SIQUEIRA et al., 2016b). The model runs with daily or hourly time step, although some internal calculation processes, such as streamflow routing always uses a smaller time steps. Most of the MGB-IPH applications have been used a daily time step (FAN; COLLISCHONN, 2014; PONTES et al., 2015). In the present work, we applied the hydrological model for flood forecasting with an hourly time-step since 2013.

The spatial variability of the relief is considered using a Digital Elevation Model (DEM). The spatial variability of vegetation, land use and soil type within the basin are considered using the Hydrological Response Classes (HRC) approach. The HRC's are areas of similar hydrological behavior, defined by the combined land use and soil type maps (FAN et al., 2015b). Combining the HRC map with each catchment generates the Hydrological Response Units (HRU), where the vertical hydrological balances are processed.

Soil water balance is performed using a method based on the surface runoff by excess of soil capacity storage that uses a probabilistic relationship between soil moisture and the fraction of saturated soil area. Evapotranspiration is estimated by the Penman-Monteith equation. 
Streamflow generation in the basin and its propagation to the river network is performed in two steps. First streamflow is generated inside each catchment and then routed to the stream network using three linear reservoirs (representing base flow; subsurface flow and surface flow). The output streamflow of those reservoirs is summed and routed along the river network using the Muskingum-Cunge flow routing method.

The MGB-IPH model parameters were first set for the Uruguay river basin based on the parameters used by Andreolli et al. (2006) to simulate the basin, and later were refined in the context of a research and development project (BELTRAME, 2012). Calibration performance to the upper Uruguay river basin is presented at Table 2. Used performance metrics were: (i) Discharges Nash Sutcliffe coefficient NS (NASH; SUTCLIFFE, 1970); (ii) Discharges Logarithm Nash Sutcliffe coefficient NSlog; and (iii) volume error (mean discharge error).

In general words, calibration was considered good enough for forecasting purposes in the basin. The median values of NS, NSlog and Volume Error performance metrics were 0.6, 0.7 and $-2 \%$.

In the context of real-time forecasting, the model includes a method of data assimilation, when it is said that the model works in "update mode" or operating "on- line". The data assimilation method in the MGB-IPH model is conducted through an empirical method that uses real time observed flow rates to update the initial conditions of the MGB-IPH model, represented by the flow calculated along the drainage network and the volume of water stored in the catchments reservoirs (MELLER; BRAVO; COLLISCHONN, 2012; FAN; MELLER; COLLISCHONN, 2015).

For the application in the Uruguay river basin the data assimilation method of the MGB-IPH model was activated and used in the system operation.

\section{OPERATIONAL FORECASTING ASSESSMENTS AND DISCUSSIONS}

The daily Uruguay forecasting system predictions were recorded since July 2013 until July 2016 for the system evaluation. In the following sections is presented the results obtained until the end of the system operation. All results are inflow assessments.

First, is showed a visual assessment of some of the past floods forecasted. Second, the system performance is evaluated by comparing forecasts with observed discharges using performance metrics commonly used in hydrological modelling studies: (i) Nash

Table 2. Performance metrics of the MGB-IPH model calibration.

\begin{tabular}{ccccc}
\hline ID & Nome & NS & NSlog & Volume Error (\%) \\
\hline 1 & Passo-do-Honorato & 0.70 & 0.71 & -22.5 \\
2 & Santana & 0.22 & 0.68 & -3.1 \\
3 & Socorro & 0.33 & 0.10 & -21.3 \\
4 & Vacas-Gordas & 0.60 & 0.73 & -30.2 \\
5 & Barra Grande & 0.80 & 0.85 & -22.5 \\
6 & Bocaina do Sul & 0.99 & 0.93 & -0.7 \\
7 & Ponte Alta & 0.98 & 0.93 & -0.7 \\
8 & Travessão & 1.00 & 0.96 & -0.4 \\
9 & Garibaldi & 0.64 & 0.47 & -1.2 \\
10 & Campos Novos & 0.61 & 0.21 & -1.3 \\
\hline
\end{tabular}

Sutcliffe coefficient NS (NASH; SUTCLIFFE, 1970); (ii) Persistence Coefficient (PC); (iii) Mean Absolute Error (MAE); and (iv) Root Mean Square Error (RMSE).

The Nash-Sutcliffe coefficient (Equation 1) allows a comparison between the results predicted and the mean of all observed streamflows. The closer its value is to one the better are the results of forecasts. On the other hand, negative values indicate that using the averaged observed value as the predicted value provide a better results.

The PC shown in Equation 2, allows a comparison between forecasted results and a hypothetical model that predicts, for all time intervals over the forecast horizon, the last observed value (hence the name "persistence"). It is also known as "today is equal to yesterday" model. The forecasts results are better as closer the PC value is to one. When PC values are less than zero, using the last observed value performs better than the prediction value.

The Mean Absolute Error (Equation 3) measures the average absolute difference between the predicted and observed values. The results of forecasts are better as closer the MAE value is to zero. Finally, the Root Mean Square Error (Equation 4) measures the root mean square difference between the forecasted and observated values. Again, the closer its value is to zero, the better the results of forecasts. Compared to the MAE, the RMSE helps to understand the distribution of the errors in the forecast, since it gives greater weight to larger deviations.

$$
\begin{aligned}
& \mathrm{NS}=\frac{\sum_{\mathrm{n}=1}^{\mathrm{N}}\left(\mathrm{Qo}_{\mathrm{i}}-\mathrm{Qp}_{\mathrm{i}}\right)^{2}}{\sum_{\mathrm{n}=1}^{\mathrm{N}}\left(\mathrm{Qo}_{\mathrm{i}}-\mathrm{Qo}_{\mathrm{m}}\right)^{2}} \\
& \mathrm{PC}=\frac{\sum_{\mathrm{n}=1}^{\mathrm{N}}\left(\mathrm{Qo}_{\mathrm{i}}-\mathrm{Qp}_{\mathrm{i}}\right)^{2}}{\sum_{\mathrm{n}=1}^{\mathrm{N}}\left(\mathrm{Qo}_{\mathrm{i}}-\mathrm{Qo}_{\mathrm{t}}\right)^{2}} \\
& \mathrm{EMA}=\frac{1}{\mathrm{~N}} \sum_{\mathrm{n}=1}^{\mathrm{N}}\left|\mathrm{Qp}_{\mathrm{i}}-\mathrm{Qo}_{\mathrm{i}}\right| \\
& \mathrm{REMQ}=\left(\frac{1}{\mathrm{~N}} \sum_{\mathrm{n}=1}^{\mathrm{N}}\left(\mathrm{Qo}_{\mathrm{i}}-\mathrm{Qp}_{\mathrm{i}}\right)^{2}\right)^{1 / 2}
\end{aligned}
$$

where Qo $\left[\mathrm{m}^{3} / \mathrm{s}\right]$ is the observed streamflow, Qp $\left[\mathrm{m}^{3} / \mathrm{s}\right]$ and i $[\mathrm{h}]$ are, respectively, the streamflow and lead time forecasts, and $\mathrm{N}$ is the total number of issued forecasts.

Results shown here are evaluated at Barra Grande and Campos Novos HPP dams, located at the upper region of the Uruguay River basin (Figure 1).

\section{Visual assessments}

Visual assessments of extreme events inflow forecasts for the Barra Grande HPP Dam are presented following. Figure 3, Figure 4 and Figure 5 shows three cases of successful forecasts of high flow events, while Figure 6 shows a case in which forecasts generated false alarms. In all cases, forecasted hydrographs are shown in blue lines and observed hydrographs are shown in black 


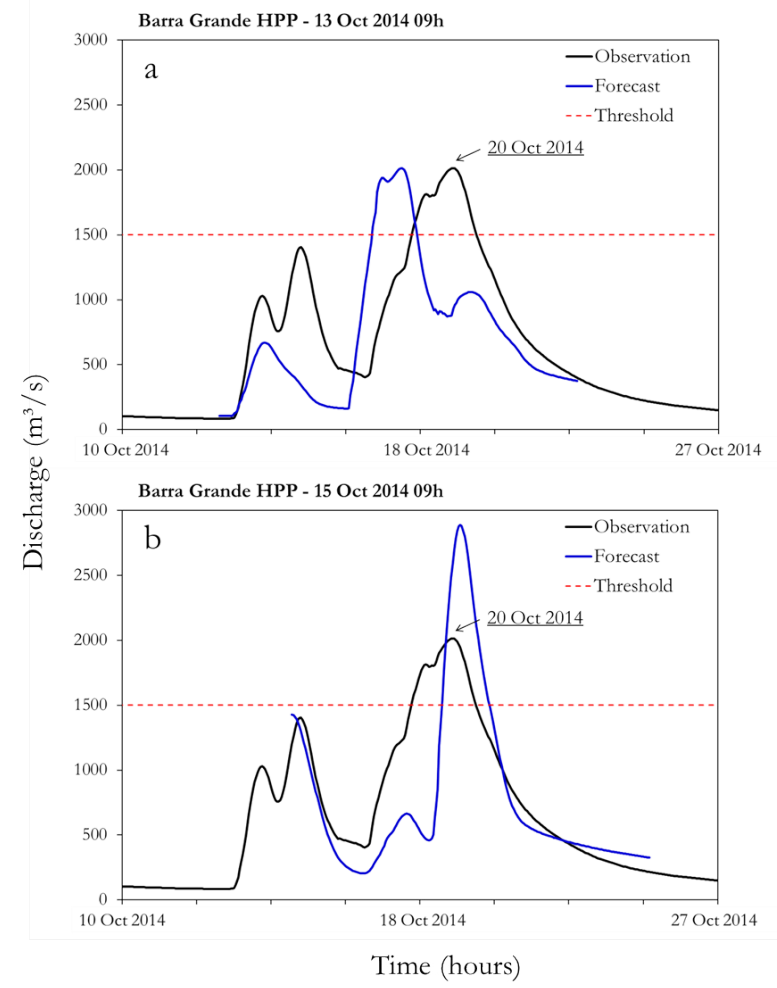

Figure 3. Sequence of forecasts for a flooding event at 20 October 2014 for Barra Grande HPP: (a) Forecast issued at 15 October 2014; and (b) Forecast issued at 20 October 2014.

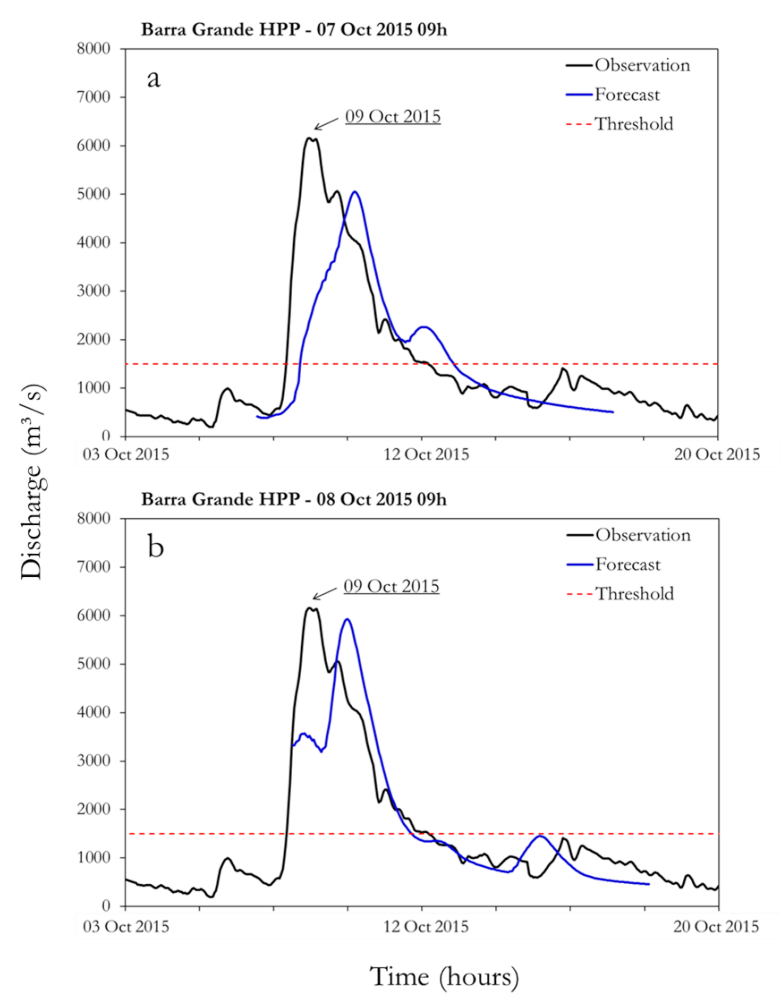

Figure 4. Sequence of forecasts for a flooding event at 09 October 2015 for Barra Grande HPP: (a) Forecast issued at 07 October 2015; and (b) Forecast issued at 08 October 2015.

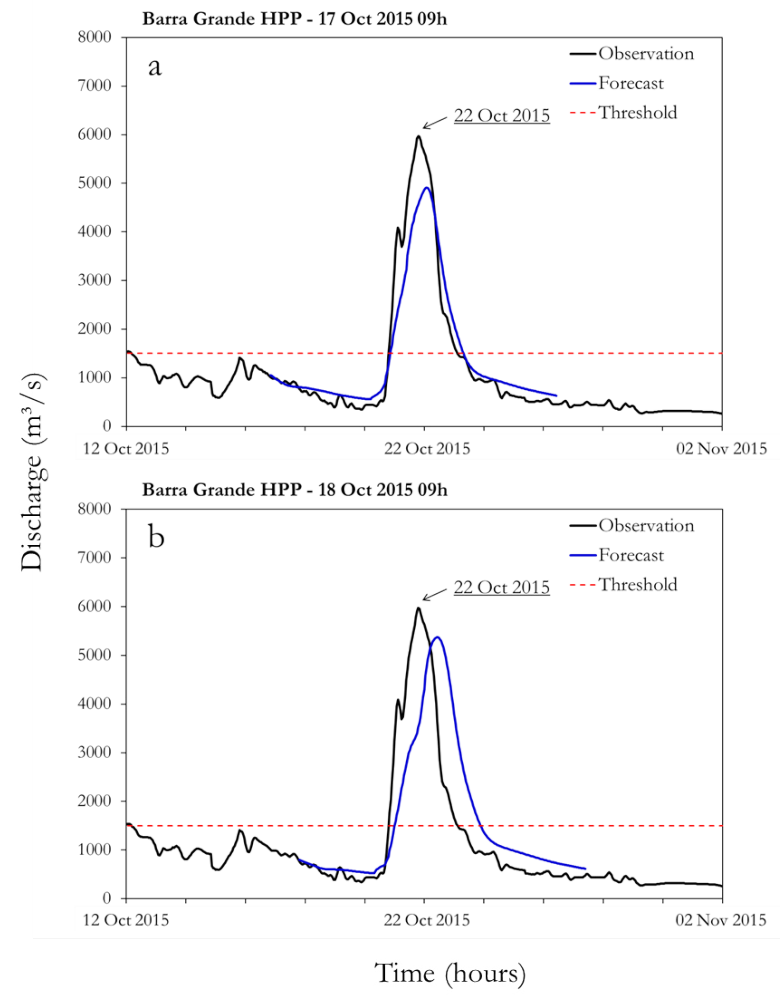

Figure 5. Sequence of forecasts for a flooding event at 22 October 2015 for Barra Grande HPP: (a) Forecast issued at 17 October 2015; and (b) Forecast issued at 18 October 2015.

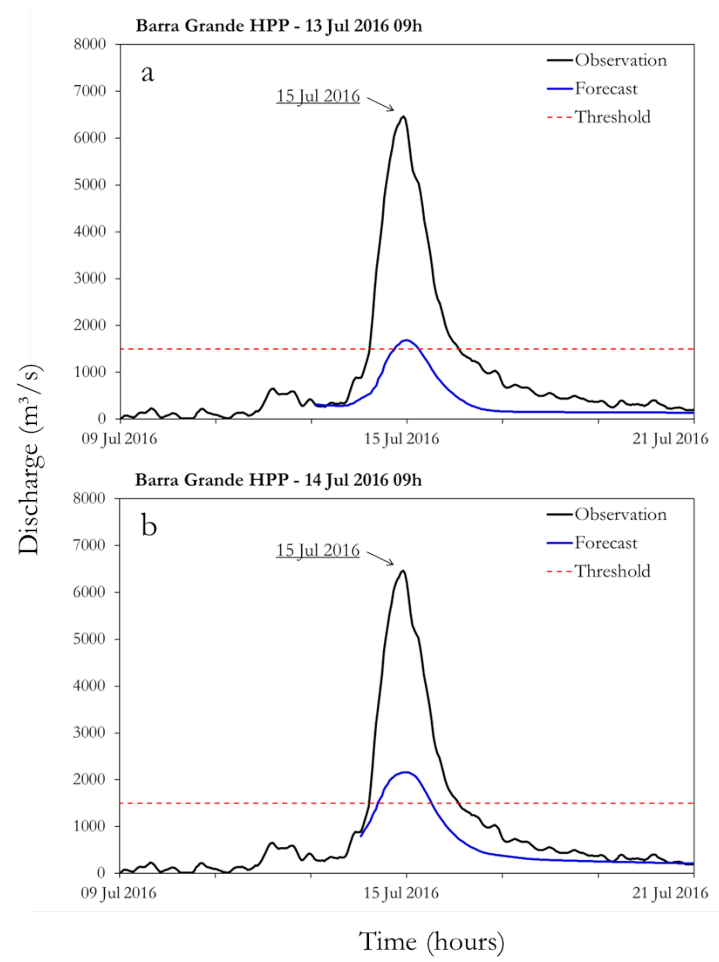

Figure 6. Example of unsuccessful forecast issued by the system. Sequence of forecasts for a flooding event at 15 July 2016 for Barra Grande HPP: (a) Forecast issued at 13 July 2016; and (b) Forecast issued at 14 July 2016. 
line. The red line is the inflow threshold value operationally used as a reference for floods occurrence in the dams $\left(1500 \mathrm{~m}^{3} / \mathrm{s}\right)$.

Both graphs shown in Figure 3 are for the same flood event. This event had its observed peak of $2000 \mathrm{~m}^{3}$ / s at 20 October 2014, as marked on the hydrographs. As can be observed, the Barra Grande HPP basin flood peaks are fast, growing from $500 \mathrm{~m}^{3} / \mathrm{s}$ to $2000 \mathrm{~m}^{3} / \mathrm{s}$ in nearly 24 hours. The graph of Figure 3 a shows the forecast issued in the morning of 13 October, i.e. seven days before the peak that actually occurred. The second graph (Figure 3b) shows the forecast issued on 15 October, i.e. five days before the peak that actually occurred. It can be observed that the forecast issued in 13 October correctly predicted the high flow event occurrence only with an error of some hours in the timing of the event. Two days later, the forecast of 15 October still correctly shows a streamflow peak, although the value of the peak was not perfect, the forecast was very persistent on indicating the event occurrence.

The second event (Figure 4) corresponds to a flow peak of approximately $6000 \mathrm{~m}^{3} / \mathrm{s}$ occurred at 09 October 2015 . The possible occurrence of a high flow at this day was predicted two days in advance by the forecast issued in 07 October 2014, presenting a flow peak near to that observed value. The flow peak was persistently predicted by the system one in advance, at 08 October 2015.

The third analyzed event (Figure 5) was another inflow peak of approximately $6000 \mathrm{~m}^{3} / \mathrm{s}$ occurring at 22 October 2015 . In this case, the system alerted for possible elevated inflow events five days in advance (forecast issued at 17 October 2015) to the occurrence of the inflow peak. The event was persistently forecasted in the sequence of forecasts, as an example, at 18 October 2015, although with some timing lag.

The cases presented in Figures 3, 4 and 5 shows forecasts with reasonable quality. However, as shown in Figure 6, this pattern was not always observed.

Figure 6 shows a sequence of two forecasts issued in respectively at 13 and 14 July 2016, both not predicting the flow peak of $6800 \mathrm{~m}^{3} / \mathrm{s}$ at 15 July 2016. At least at both forecasts the attention threshold was identified by the system, minimizing eventually damages related to the situation to be considered normal.

We believe that these unsuccessful forecasts were due to a combination of facts: (i) the real spatial rainfall over the basin was not well surveyed by the existing rain gauging stations; (ii) the NWP model did not shows a precisely prediction of the amounts of rainfall over the basin for different lead-times; (iii) the Barra Grande HPP basin is very sensitive to rainfalls location, and possibly the forecasted rainfall was not over the most rainfall sensitive region of the basin, where it truly occurred (spatial bias).

Figure 7 and Figure 8 present forecasts for two cases at the Campos Novos HPP. The first case (Figure 7) is a high flow event with $2500 \mathrm{~m}^{3} / \mathrm{s}$ peak at 02 October 2014 , as marked on the hydrographs. The first graph (Figure 7a) shows the forecast issued in the morning of 29 September 2014, i.e. four days before the peak actually occurred. The second graph (Figure $7 \mathrm{~b}$ ) shows the forecast issued at 02 October 2014, i.e. one day before the peak actually occurred. It can be seen that both forecasts persistently issued the occurrence of the high flow event, with an increasing quality of the recent forecasts for the peak value.

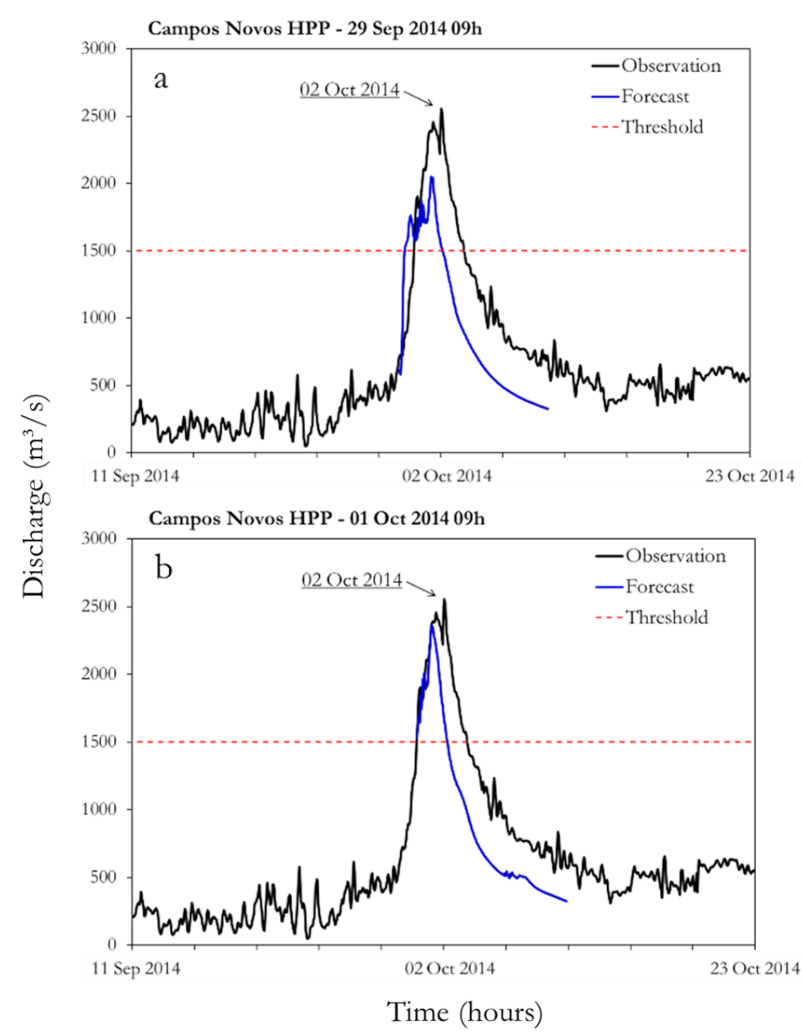

Figure 7. Sequence of forecasts for a flooding event at 02 October 2014 for Campos Novos HPP: (a) Forecast issued at 02 October 2014; and (b) Forecast issued at 01 October 2014.

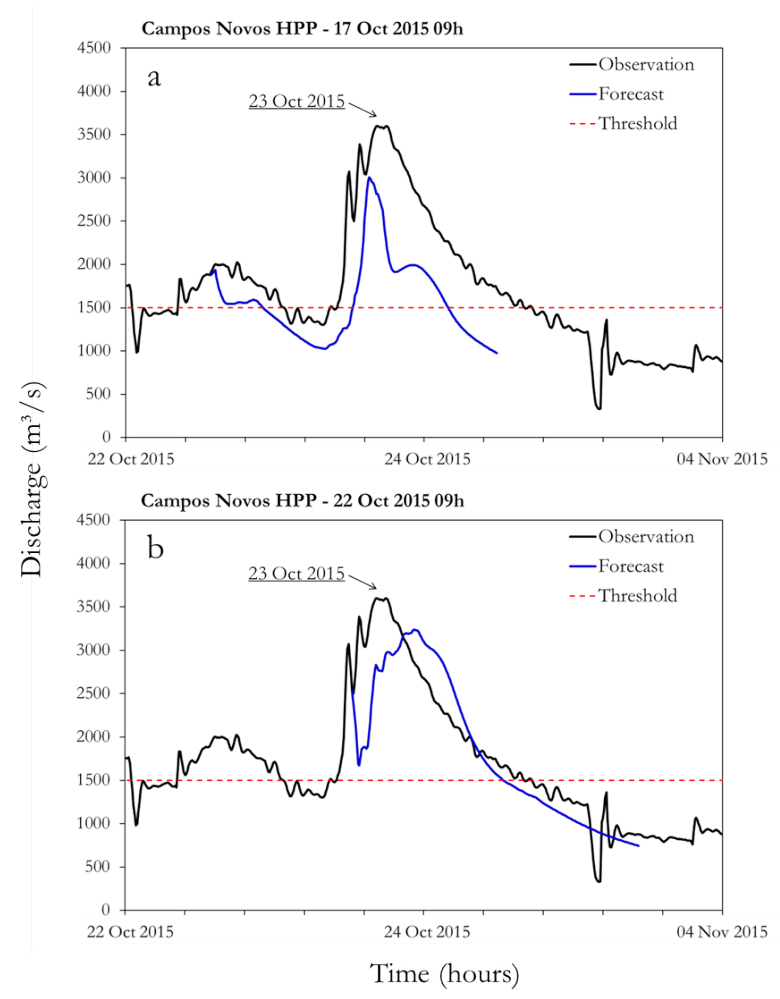

Figure 8. Sequence of forecasts for a flooding event at 23 October 2015 for Campos Novos HPP: (a) Forecast issued at 17 October 2015; and (b) Forecast issued at 22 October 2015. 
The second case (Figure 8 ) is part of a sequence of events with a peak inflow of $3600 \mathrm{~m}^{3} / \mathrm{s}$ at 23 October 2015 . The first graph (Figure 8a) shows the forecast issued in the morning of 17 October 2015, with the correctly indication of a flood over the threshold six days prior to the event. The second graph shows the forecast issued at 22 October 2015, when the inflow was already elevated, the flood volume occurrence was well forecasted, but with some overestimation in terms of peak value and timming.

\section{Metrics assessments}

Figure 9 and Figure 10 present an analysis of the lead time performance of the hydrological forecasting system, performed using the metrics explained.

Regarding the results presented in Figure 9 (Barra Gande HPP), for lead times lower or equal to 160 hours (6,5 days) the NS coefficient values were positive, indicating that using model results as the predicted value is better than using the average of the observed data set until this lead time. The PC results indicate an important characteristic of fast-response river basins, such as the upper Uruguay one, that is not very convenient use as a prediction the last observed values for longer than 10 hours. Due to this fact, auto-regressive models usually perform poorly in this region. The basin has a very fast response to rainfall, and one can have wrong forecasts if relying only in the last observed flow values. This is shown by the positive values of the PC metric after 10h lead times, as presented in Figure 9. By the point of view of a rainfall-runoff forecasting system, this result suports the developed system importance, being considered very positive.

Analysis of the Mean Absolute Error shown in Figure 9 (Barra Grande HPP) indicates errors lower than $310 \mathrm{~m}^{3} / \mathrm{s}$. These errors values can be considered low if compared to the magnitude of flooding's, that are presented in the visual assessments (up to $6000 \mathrm{~m}^{3} / \mathrm{s}$ ). For the root mean square error, the interpretation of results in terms of lead time is similar to MAE. Also, if we compare the values and behavior of RMSE with EMA it is possible to say that the errors are well distributed among the forecasts and lead times, since they have similar curves behaviors, there are no greater discrepancies highlighted by the RMSE.

Regarding the results presented in Figure 10 (Canoas HPP), values of the NS coefficient were positive over all lead times. These results showing that the model is always better than using average of the observed data set, as predicted value. The results obtained for the PC also indicate that using the last observed values as the prediction is not very appropriate from $22 \mathrm{~h}$ lead times ahead, in comparison to the forecasting system, since PC values from this lead time are always above zero.

Analysis of the Mean Absolute Error shown in Figure 10 (Campos Novos HPP) indicates errors lower than $255 \mathrm{~m}^{3} / \mathrm{s}$.

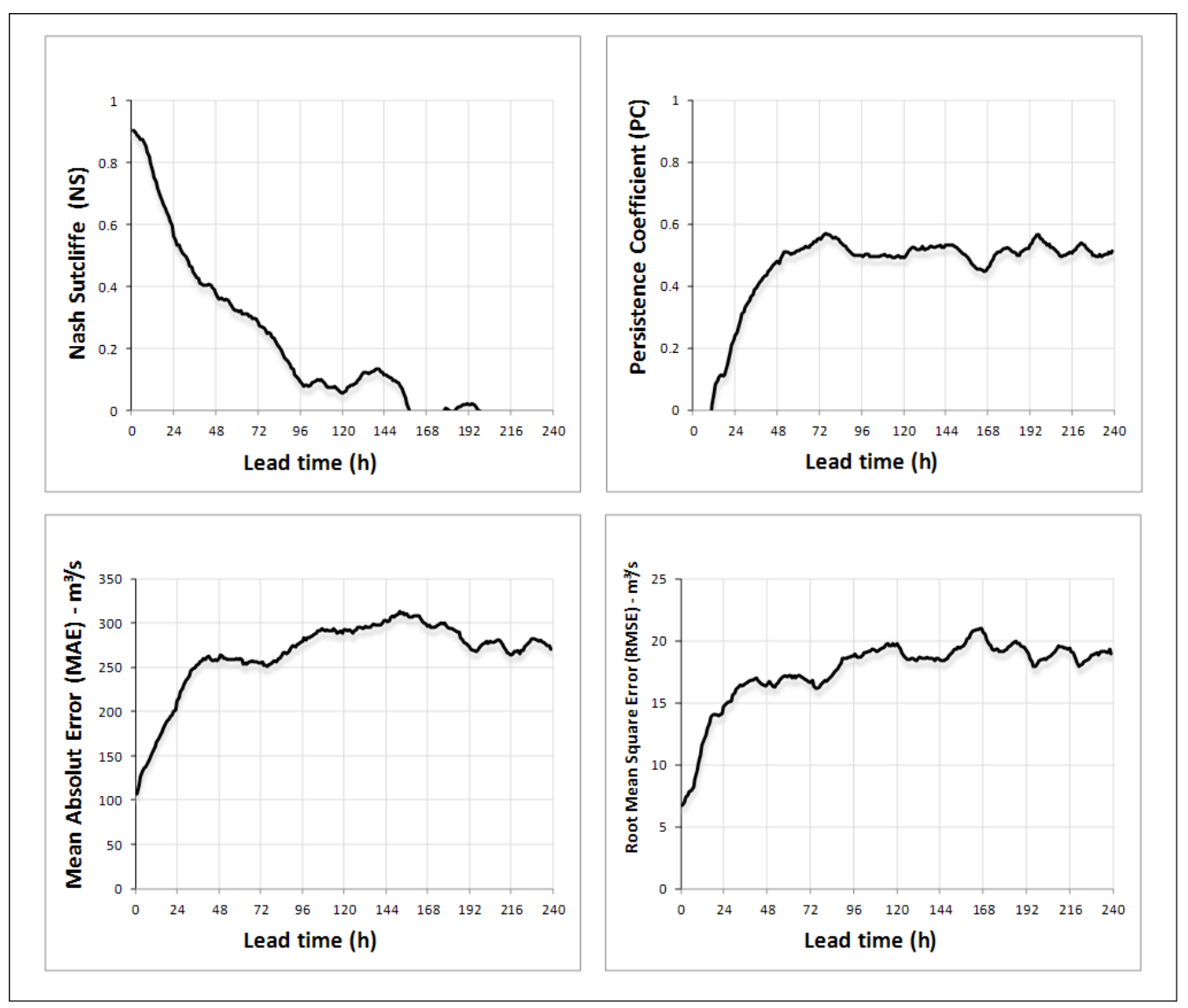

Figure 9. Lead time performance analysis of the hydrological forecasting system for Barra Grande HPP using four different metrics: Nash Sutcliffe coefficient for flows (NS), Persistence Coefficient (PC), Mean Absolut Error (MAE), and Root Mean Square Error (RMSE). 
Over, these errors values can be considered low if compared to the magnitude of flooding's, that are presented in the visual assessments. For example, $255 \mathrm{~m}^{3} / \mathrm{s}$ is less than $10 \%$ of the flood peaks assessed previously. Also, this error has a relationship with the uncertainty of observations that are very noise due to water balance back calculation in the reservoir. For the root mean square error, it is again possible to say that the errors are well distributed among the forecasts and lead times, since both metrics have similar curves behavior in comparison to the MAE, there are no greater discrepancies highlighted by the RMSE.

\section{What are the differences and similarities within the forecasted systems?}

Although both studied river basins are located at Uruguay's headboard, they have different hydrological behavior. Regarding the differences on relief, the Campos Novos HPP basin has floodplain areas at its upper region. Regarding soil profile differences, Barra Gande HPP basin has less capacity of water storage. These feature makes the Campos Novos HPP basin runoff response slower than the Barra Grande HPP one, thus, the flood forecasting in the Campos Novos HPP basin usually has better results. This hypothesis is confirmed when we analyzed the system performance metrics and by the visual assessment as well.
Furthermore, rainfall forecasts play an important role on system performance. Since CPTEC ETA- $15 \mathrm{~km}$ is a deterministic model, several forecasted rainfalls may present unknown uncertainty about an event magnitude and/or occurrence and about the spatial position of the event within the basin. These errors were shown in Figure 5. This is especially important for Barra Grande HPP basin, because it is more sensible to rainfall spatial and temporal errors.

This kind of analysis elucidates that in a hydro-meteorological forecasting system the watershed component plays a very important role in the forecasting performance. Even two very near regions, such as the ones studied here, can have a noticeable different performance.

Despite this, we believe that the forecasting system had acceptable performances during the analyzed period (since July 2013 until July 2016) for both watersheds. The Barra Grande HPP and Campos Novos HPP have low MAE compared with the inflow floods magnitude and positive NS for longer lead times. $\mathrm{CP}$ values also shows that a forecasting system that includes rainfall forecasts is important due to the basin low dependency of las observed values.

In comparison to analogous studies presented in the literature we consider that the Barra Gande HPP and the Campos Novos HPP forecasts have a performance like other results. Non-detection of thresholds or peak values are also reported by Thiemig et al. (2010), Alfieri et al. (2014), Pagano (2014) and

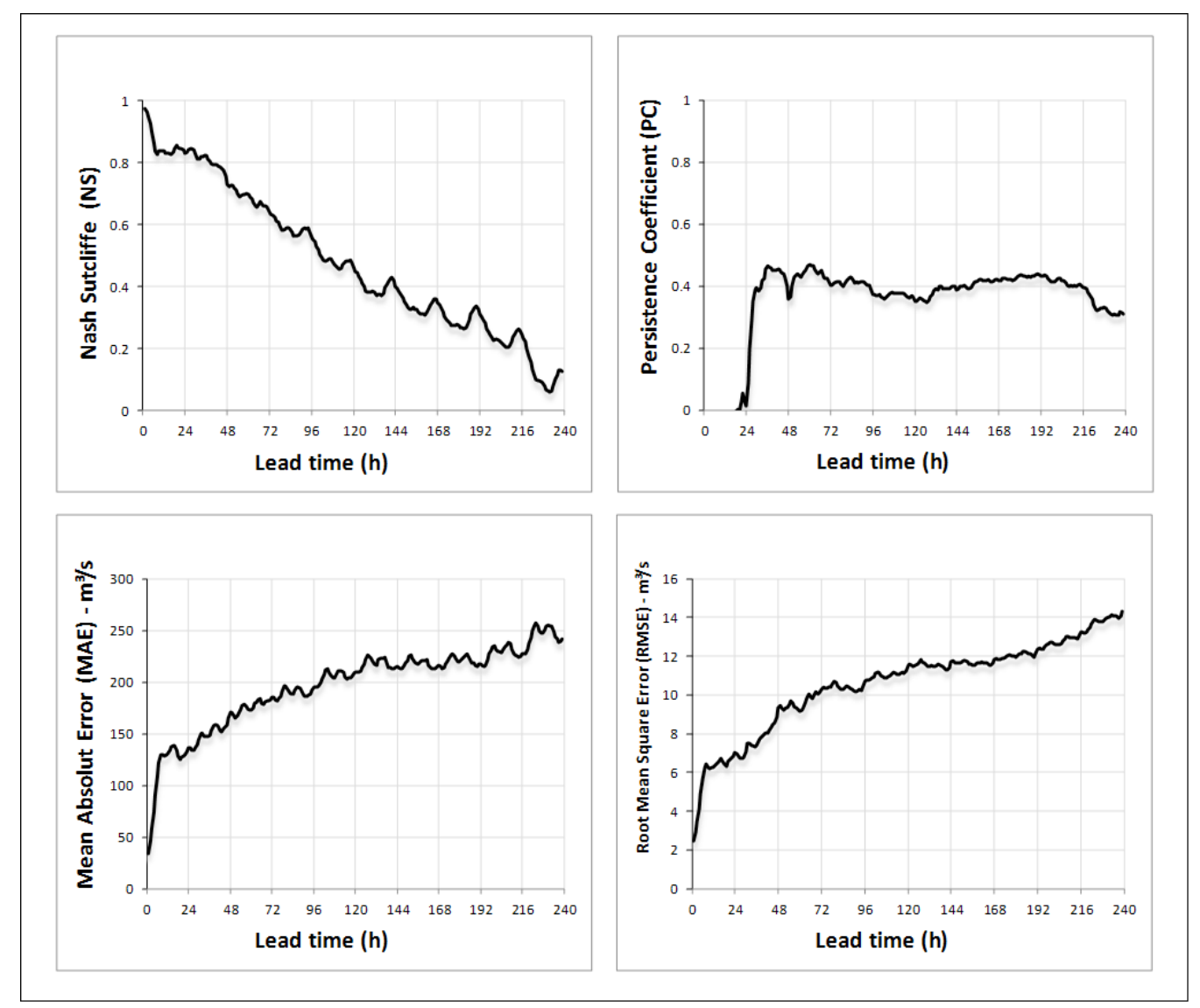

Figure 10. Lead time performance analysis of the hydrological forecasting system for Campos Novos HPP using four different metrics: Nash Sutcliffe coefficient for flows (NS), Persistence Coefficient (PC), Mean Absolut Error (MAE), and Root Mean Square Error (RMSE). 
Siqueira et al. (2016a) . In terms of metrics, Pagano (2014) found for 1 -day ahead NS values of 0.99 and CP for 1-day ahead forecasts typically around $0.4-0.8$ and for 5-day ahead forecasts typically around $0.1-0.7$. Those values are in the same order of the ones found in the present cases, with elevated NS values at initial lead times, and CP values greater than zero over almost all lead-times.

\section{CONCLUSIONS}

This study showed an assessment of results of an experimental operational flow forecasting system of the Upper Uruguay River basin, located in southern, Brazil. To evaluate the forecasting system were used the predictions produced daily from the model since the beginning of its operation, in July 2013 until the end, in July 2016.

For the Barra Grande HPP inflow, visual assessments showed that the predictions have good agreement with observed inflows estimative, predicting the possible occurrence of floods with 2 to 3 days in advance, which is normally confirmed by the predictions issued with smaller lead times. This is consistent with the performance lead time analysis, where we showed that the best performance of the model is for these lead times.

For the Campos Novos HPP inflow, the results assessments show that the system predictions have an adequate performance to almost all lead times. This performance is better than the one observed to the Barra Grande HPP.

We would like to give highlights to results obtained with the persistence coefficient, which showed the importance of considering the rainfall-runoff transformation in the forecast, what is related to the rapid response of the basin to rainfall events. Also, we would like to highlight that even being very spatially near river basins, forecasted inflow performances are noticeable different between Campos Novos HPP basin and Barra Grande HPP basin. This gives a reference about the importance of the hydrological modelling component of the hydro-meteorological system.

Regardless of the overall good results obtained, the visual analysis also showed that flow forecasts may result in an error. Based in the system operation experience, we attribute this mainly to the non-perception of rainfall by the existing gauges in the basin and due to uncertainties at the forecasted rainfall from meteorological model.

To improve the shorter-term parts of forecasts, we believe that one solution would be: To increase the rainfall telemetric gauges and using rainfall from a radar system. This would also need the recalibration of the hydrological model to consider the new datasets.

To enhance the longer-term flow predictions a probabilistic forecasts test based on ensembles of rainfall forecasts could be carried out using different meteorological models, each of them running with different initial conditions, such the ones presented by Meller, Bravo and Collischonn (2012), Fan et al. (2014), Fan, Ramos and Collischonn (2015), or Siqueira et al. (2016a).

As well, improvements in the hydrological model and data assimilation schema may be useful. These suggestions will be the subject of attention for forthcoming research related to the hydrological forecasting system of the Uruguay River basin.

\section{REFERENCES}

ADDOR, N.; JAUN, S.; FUNDEL, F.; ZAPPA, M. An operational hydrological ensemble prediction system for the city of Zurich (Switzerland): skill, case studies and scenarios. Hydrology and Earth System Sciences, v. 15, n. 7, p. 2327-2347, 2011. http://dx.doi. org/10.5194/hess-15-2327-2011.

ALFIERI, L.; PAPPENBERGER, F.; WETTERHALL, F; HAIDEN, T.; RICHARDSON, D.; SALAMON, P. Evaluation of ensemble streamflow predictions in Europe. Journal of Hydrology, v. 517, p. 913-922, 2014. http://dx.doi.org/10.1016/j.jhydrol.2014.06.035.

ALFIERI, L.; SALAMON, P.; PAPPENBERGER, F.; WETTERHALL, F.; THIELEN, J. Operational early warning systems for waterrelated hazards in Europe. Environmental Science \& Policy, v. 21, p. 35-49, 2012. http://dx.doi.org/10.1016/j.envsci.2012.01.008.

ANDREOLLI, I.; TUCCI, C.; REGINA, J.; HAAS, R.; COLLISCHONN, W. Previsão de vazão afluente a um reservatório utilizando previsão quantitativa de chuva. Revista Brasileira de Recursos Hidricos, v. 11, n. 3, p. 55-69, 2006. http://dx.doi.org/10.21168/ rbrh.v11n3.p55-69.

BAO, H.-J.; ZHAO, L.-N.; HE, Y.; LI, Z.-J.; WETTERHALL, F.; CLOKE, H. L.; PAPPENBERGER, F.; MANFUL, D. Coupling ensemble weather predictions based on TIGGE database with Grid-Xinanjiang model for flood forecast. Advances in Geosciences, v. 29, p. 61-67, 2011. http://dx.doi.org/10.5194/adgeo-29-61-2011.

BELTRAME, L. F. S. Previsão de vazões afluentes a reservatórios de usinas hidrelétricas nas bacias dos rios Pelotas e Taquari-Antas com base em previsão quantitativa de chuva. Porto Alegre: Universidade Federal do Rio Grande do Sul, 2012. 90 p. Relatório Final de Projeto de P\&D ANEEL. Termo de Cooperação Técnica Nº 3936-11.

BERGH, J.; ROULIN, E. Hydrological ensemble prediction and verification for the Meuse and Scheldt basins. Atmospheric Science Letters, v. 11, n. 2, p. 64-71, 2010.

BOUCHER, M.-A.; ANCTIL, F.; PERREAULT, L.; TREMBLAY, D. A comparison between ensemble and deterministic hydrological forecasts in an operational context. Advances in Geosciences, v. 29, p. 85-94, 2011. http://dx.doi.org/10.5194/adgeo-29-85-2011.

BOURDIN, D. R.; STULL, R. B. Bias-corrected short-range member-to-member ensemble forecasts of reservoir inflow. Journal of Hydrology, v. 502, p. 77-88, 2013. http://dx.doi.org/10.1016/j. jhydrol.2013.08.028.

CASAGRANDE, L.; TOMASELLA, J.; SANTOS ALVALÁ, R. C.; BOTTINO, M. J.; CARAM, R. O. Early flood warning in the Itajaí-Açu River basin using numerical weather forecasting and hydrological modeling. Natural Hazards, 2017. In press. http:// dx.doi.org/10.1007/s11069-017-2889-0.

COLLISCHONN, W.; ALLASIA, D. G.; SILVA, B. C.; TUCCI, C. E. M. The MGB-IPH model for large-scale rainfall-runoff 
modelling. Hydrological Sciences Journal, v. 52, n. 5, p. 878-895, 2007. http://dx.doi.org/10.1623/hysj.52.5.878.

FAN, F. M.; COLLISCHONN, W. Integração do modelo MGBIPH com sistema de informação geográfica. Revista Brasileira de Recursos Hídricos, v. 19, n. 1, p. 243-254, 2014. http://dx.doi. org/10.21168/rbrh.v19n1.p243-254.

FAN, F. M.; COLLISCHONN, W.; MELLER, A.; BOTELHO, L. C. M. Ensemble streamflow forecasting experiments in a tropical basin: The São Francisco river case study. Journal of Hydrology, v. 519, p. 2906-2919, 2014. http://dx.doi.org/10.1016/j. jhydrol.2014.04.038.

FAN, F. M.; SCHWANENBERG, D.; COLLISCHONN, W.; WEERTS, A. Verification of inflow into hydropower reservoirs using ensemble forecasts of the TIGGE database for large scale basins in Brazil. Journal of Hydrology: Regional Studies, v. 4, p. 196-227, 2015a.

FAN, F. M.; BUARQUE, D. C.; PONTES, P. R. M.; COLLISCHONN, W. Um mapa de Unidades de Resposta Hidrológia para a América do Sul. In: SIMPÓSIO BRASILEIRO DE RECURSOS HÍDRICOS, 21., 2015, Brasília. Anais... Porto Alegre: ABRH, 2015b. p. PAP019919.

FAN, F. M.; COLLISCHONN, W.; QUIROZ, K. J.; SORRIBAS, M. V.; BUARQUE, D. C.; SIQUEIRA, V. A. Flood forecasting on the Tocantins River using ensemble rainfall forecasts and real-time satellite rainfall estimates. Journal of Flood Risk Management, v. 9, n. 3, p. 278-288, 2015c. http://dx.doi.org/10.1111/jfr3.12177.

FAN, F. M.; MELLER, A.; COLLISCHONN, W. Incorporação de filtro numérico de separação de escoamento na assimilação de dados para previsão de vazões utilizando modelagem hidrológica. Revista Brasileira de Recursos Hídricos, v. 20, n. 2, p. 472-483, 2015. http://dx.doi.org/10.21168/rbrh.v20n2.p472-483.

FAN, F. M.; PAIVA, R. C. D.; COLLISCHONN, W. Hydrological forecasting practices in Brazil. In: ADAMS, T. E.; PAGANO, T. C. (Ed.). Flood forecasting: a global perspective. 1st ed. Amsterdam: Academic Press, 2016. p. 41-66. v. 1.

FAN, F. M.; RAMOS, M. H.; COLLISCHONN, W. Sobre o uso de previsões hidrológicas probabilísticas para tomada de decisão. Revista Brasileira de Recursos Hídricos, v. 20, n. 4, p. 914-926, 2015. http://dx.doi.org/10.21168/rbrh.v20n4.p914-926.

FAN, F. M.; SCHWANENBERG, D.; ALVARADO, R.; REIS, A. A.; COLLISCHONN, W.; NAUMANN, S. Performance of deterministic and probabilistic hydrological forecasts for the short-term optimization of a tropical hydropower reservoir. Water Resources Management, v. 30, p. 1-17, 2016. http://dx.doi. org/10.1007/s11269-016-1377-8.

MELLER, A.; BRAVO, J. M.; COLLISCHONN, W. Assimilação de dados de vazão na previsão de cheias em tempo-real com o Modelo Hidrológico MGB-IPH. Revista Brasileira de Recursos Hídricos, v. 17, n. 3, p. 209-224, 2012. http://dx.doi.org/10.21168/rbrh. v17n3.p209-224.

MOORE, R. J.; BELL, V. A.; JONES, D. A. Forecasting for flood warning. Comptes Rendus Geoscience, v. 337, n. 1-2, p. 203-217, 2005. http://dx.doi.org/10.1016/j.crte.2004.10.017.

NARDY, A. J. R.; OLIVEIRA, M. A. F.; BETANCOURT, R. H. S.; VERDUGO, D. R. H.; MACHADO, F. B. Geologia e estratigrafia da Formação Serra Geral. Revista Geociências, v. 21, p. 15-32, 2002.

NASH, J. E.; SUTCLIFFE, J. V. River flow forecasting through conceptual models part I: a discussion of principles. Journal of Hydrology, v. 10, n. 3, p. 282-290, 1970. http://dx.doi.org/10.1016/00221694(70)90255-6.

PAGANO, T. C. Evaluation of Mekong River commission operational flood forecasts, 2000-2012. Hydrology and Earth System Sciences, v. 18, n. 7, p. 2645-2656, 2014. http://dx.doi.org/10.5194/ hess-18-2645-2014.

PAGANO, T.; WOOD, A.; RAMOS, M.; CLOKE, H.; PAPPENBERGER, F.; CLARK, M.; CRANSTON, M.; KAVETSKI, D.; MATHEVET, T.; SOROOSHIAN, S.; VERKADE, J. Challenges of Operational River Forecasting. Journal of Hydrometeorology, v. 15, n. 4, p. 1692-1707, 2014. http://dx.doi.org/10.1175/ JHM-D-13-0188.1.

PONTES, P. R. M.; COLLISCHONN, W.; FAN, F. M.; PAIVA, R. C. D.; BUARQUE, D. C. Modelagem hidrológica e hidráulica de grande escala com propagação inercial de vazões. Revista Brasileira de Recursos Hídricos, v. 20, n. 4, p. 888-904, 2015. http://dx.doi. org/10.21168/rbrh.v20n4.p888-904.

PONTES, P. R. M.; FAN, F. M.; FLEISCHMANN, A. S.; PAIVA, R. C. D.; BUARQUE, D. C.; SIQUEIRA, V. A.; JARDIM, P. F.; SORRIBAS, M. V.; COLLISCHONN, W. MGB-IPH model for hydrological and hydraulic simulation of large floodplain river systems coupled with open source GIS. Environmental Modelling \& Software, v. 94, p. 1-20, 2017. http://dx.doi.org/10.1016/j. envsoft.2017.03.029.

SCHELLEKENS, J.; WEERTS, A. H.; MOORE, R. J.; PIERCE, C. E.; HILDON, S. The use of MOGREPS ensemble rainfall forecasts in operational flood forecasting systems across england and wales. Advances in Geosciences, v. 29, p. 77-84, 2011. http:// dx.doi.org/10.5194/adgeo-29-77-2011.

SIQUEIRA, V. A.; COLLISCHONN, W.; FAN, F. M.; CHOU, S. C. Ensemble flood forecasting based on operational forecasts of the regional Eta EPS in the Taquari-Antas basin. Revista Brasileira de Recursos Hidricos, v. 21, n. 3, p. 587-602, 2016a. http://dx.doi. org/10.1590/2318-0331.011616004.

SIQUEIRA, V. A.; FLEISCHMANN, A. S.; JARDIM, P. F; FAN, F. M.; COLLISCHONN, W. IPH-hydro tools: a GIS coupled tool for watershed topology aquisition in open-source environment. Revista Brasileira de Recursos Hídricos, v. 21, n. 1, p. 274-287, $2016 \mathrm{~b}$. http://dx.doi.org/10.21168/rbrh.v21n1.p274-287. 
TACHINI, M. O Alerta de cheias e a ação da defesa civil. In: FRANK, B.; PINHEIRO, A. Enchentes na bacia do rio Itajaí: 20 anos de experiências. Blumenau: EDIFURB, 2003.

THIELEN, J.; BARTHOLMES, J.; RAMOS, M.-H.; DE ROO, A. The European flood alert system. Part 1: concept and development. Hydrology and Earth System Sciences, v. 13, n. 2, p. 125-140, 2009. http://dx.doi.org/10.5194/hess-13-125-2009.

THIEMIG, V.; PAPPENBERGER, F.; THIELEN, J.; GADAIN, H.; DE ROO, A.; BODIS, K.; DEL MEDICO, M.; MUTHUSI, F. Ensemble flood forecasting in Africa: a feasibility study in the Juba-Shabelle river basin. Atmospheric Science Letters, v. 11, p. 123131, 2010. http://dx.doi.org/10.1002/asl.266.

\section{Authors contributions}

Fernando Mainardi Fan: Initial drafting of research, literature review, data processing, generation and assessment of results, writing of the manuscript.

Paulo Rógenes Monteiro Pontes: Data processing, generation and assessment of results, and paper review.

Diogo Costa Buarque: Data processing, generation and assessment of results, and paper review.

Walter Collischonn: Initial drafting of research, research supervisor and paper review. 